\title{
Many are the Crimes Committed in the Name of Islam
}

\author{
Ali Mohammed Fakhro*
}

During the French Revolution, a cry began to spread: "Oh, Freedom, How many crimes are committed in your name!" Today, in Arab and Muslim lands, we appear to need a similar rallying call: "Oh Islam, How many crimes are committed in your name!"

The Arab and Islamic worlds do not have the right any longer to disregard or pass over in silence the crimes that sweep across the planet on a daily basis in the name of Islam. It is not only a matter of mistakes and excesses committed under the false banner of jihad for Islam. These are unspeakably crazed and wanton crimes, sordid and full of treachery. There can be no doubt that they are committed to the beat of Satan's drumming the Satan who is the enemy of both God and Man. They are terrifying events that defame Islam's reputation and disgrace Muslims, and distort the meaning and objectives of the Quranic message and key terms such as al-jihad, as well as other words that are arbitrarily wrested from their context in a Holy Quranic verse to be deployed in political skirmishes.

For can it be acceptable, under any standard of measurement, but especially under the standards of the Islamic faith which equate the unjust killing of one soul with that of killing all human souls, for one to blow himself up, or to detonate a car bomb, in the name of the religion of right, justice and balance? To target a mosque in which people are prostrate and offering their prayers? Or a church in which people whom Islam declared to be brothers, as People of the Book, are also praying? Or a school in which innocent children are sitting in rows, or a queue in which people are seeking sustenance to nourish their children and their partners, or in a crowd at a sporting event whose fans have nothing to do with political struggles or politicians? The list is long of sinful acts of violence annihilating innocent lives, devastating people unaware of the devilish conspiracies that spin in sick minds and end up filling God's universe with tears and the agonies of loss and bereavement and with orphans, widows, and wholesale destruction of any residual feelings of morality and human values in the souls of a nation's people.

No, it is not conceivable for us to remain silent regarding this oppressive, ignorant abuse of the religion of the Lord of the Heavens and the Earth, the Lord of Mercy and Love, Justice and Forgiveness. To do so would be to remain silent in front of those who would try to lie to their God, whether intentionally or not, and then encourage Arab and Muslim youth to violate the underlying fundamental objectives of their religion in a barbaric suicidal operation, something that can never be approved by God, or by any code of law, whether worldly or heavenly. In their actions they only bring the entire world to despise Muslims, and to seek 
to banish and eradicate them. They will add to the hysterical uproar against the Muslim Quran and the Muslim Prophet and their history, and lead to marginalising Arab and Muslim peoples all along the course of human civilisation.

This article does not seek to prescribe what can be done. It is simply to condemn the transactional approach to the issue that we see on the part of governments, civil society institutions, and most of all, Islamic political parties, Islamic Ulama and the bureaucracies of the Arab and Islamic summit conferences, to condemn the manner chosen by all and sundry to deal with what is taking place in the name of Islam. Here we have emphasised the matter of suicidal "jihad" because it is the most tragic and painful expression of the problem, for us, as Arabs and Muslims. But the problem goes beyond that, as it encompasses social life in the broadest sense in Arab and Muslim lands, posing the imminent threat of sectarian strife and giving some people cause to doubt the beauty and purity of their Muslim faith, and giving others a reason to abandon the faith in disgust and repugnance, in response to the cruel crimes committed in its name.

This is no longer a minor problem or a side issue; it has become the main issue, THE Issue. There is no longer any need to ask "Why?", "How?", or "Where are we headed?" When the flames are surging, as they are in many countries inhabited by Arabs and Muslims, as well as non-Muslims, then it is time for quick action to extinguish the flames, and not for soul-searching questions.

A couple of thousand wayward, deluded and possibly duped young Muslims, whose innocence and pure intentions have been exploited, can no longer be allowed to ravage the earth under the feet of a billion and a half of their fellow Muslims: Muslims who ask themselves with every new day, upon hearing the news of the atrocities that have been carried out, what catastrophe must lie ahead if things go on like this, a trend in which they are in no way supportive, much longer.

We know that some jurists of rigidly narrow-minded and backward versions of Islamic fiqh are complicit in this black theatre, but we nonetheless look to the best Islamic scholars and Muslim minds to unify ranks and speak in one voice, in a daily exhortation, from all pulpits in the mosques and from all media platforms, to combat this "jihadi" contagion which harvests the lives of innocent Muslims while in many instances remaining indifferent to the real enemies. Meanwhile, the Zionist and imperialist enemy can bide their time in peace and security as many societies go up in flames: the Iraqi, Syrian, Afghan, Yemeni, Sudanese, and Pakistani societies among others.

Islamic religious scholars, some of whom never tire of discussing life's marginal issues, trivialities and banalities, are most definitely called upon to lead a wideranging, religion-based cultural and political mobilisation, not an arbitrary and violent security clamp-down, to support and defend the religion of Islam which is 
now facing a severe historic trial involving tremendously dangerous dimensions and repercussions. But this is not about channelling Unitary [Islamic] Faith into contemptible sectarian strife, such as the meaningless oppositional Sunni-Shi' ite strife: this would only add to Islam's tribulations and the devastation of the societies of its faithful followers, and present the entire world with a picture of tragic absurdity.

Let everyone think of the torment of a day that is not far off, a day in which all will see what their hands have wrought, from the disastrous days of Afghan jihad up to the present day and, one hopes, for only a short time continuing in the future.

(Translated by Michael K. Scott, IAIS Visiting Fellow, 30 April 2013)

\section{Note}

* Ali Mohammed Fakhro, PhD, is the Chairman of the Board of Trustees of the Bahrain Centre for Studies and Research, previously serving as Bahrain's Minister of Health (1970-1982) and Minister of Education (1982-1995) and as Bahrain's Ambassador to France (1995-2000). He serves on the executive board of the World Health Organization and UNESCO and is a trustee of many regional institutions including the Institute for Arab Unity Studies, the Institute of Palestine Studies, the Bahrain Youth and Sport Council, the Arab Organization for Translation, the Arab Open University and of Written and Visual Arab Media Awards in Dubai. His weekly Arabic commentary is published by seven major Arabic newspapers from London to the Arab Gulf. A graduate of the American University in Beirut (1954), Dr. Fakhro is a Fellow in Gastroenterology and Cardiology at the Harvard School of Public Health, and the American Board of Internal Medicine (1965). 